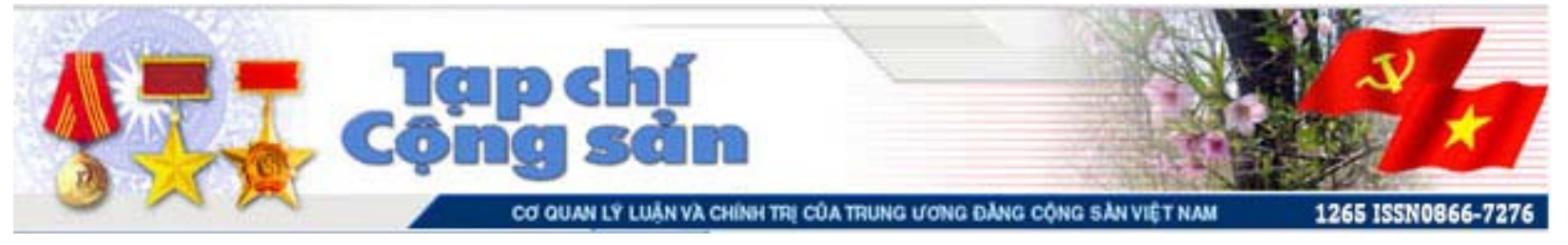

\title{
Cổ phần hóa doanh nghiệp nhà nước: Thăng trầm và đột phá
}

$16 / 3 / 201114: 27^{\prime}$

TCCS - Cổ phần hóa doanh nghiệp nhà nước (DNNN) là một bước đi mạnh dạn và cho đến nay có thể khẳng định là đúng đắn. Tuy nhiên, quá trình đó cũng đã diễn ra với nhiều thăng trầm, cam go và khó khăn, trắc trở, nhưng cũng đã đem lại bước phát triển mang tính đột phá đối với nhiều doanh nghiệp.

Nhìn lại toàn bộ quá trình đổi mới tư duy kinh tế của Đảng trong 25 năm qua, tư duy nhận thức đã có nhiều thay đổi, trong đó nội dung tổng quát và bao trùm nhất vẫn là chuyển đổi nền kinh tế kế hoạch hóa tập trung sang phát triển kinh tế thị trường định hướng xã hội chủ nghĩa. Sắp xếp, đổi mới và nâng cao hiệu quả $\mathrm{DNNN}$ là một giải pháp quan trọng trong tổng thể quá trình đó. Việc sắp xếp DNNN được thực hiện bằng các giải pháp: sáp nhập, hợp nhất, cổ phần hóa, giao, khoán, bán, cho thuê doanh nghiệp, tổ chức lại các tổng công ty nhà nước và thành lập tập đoàn kinh tế nhà nước.

Trong tất cả các giải pháp này, cổ phần hóa $\mathrm{DNNN}$ được xem là một giải pháp cơ bản và quan trọng nhất để cơ cấu lại DNNN. Thực chất cổ phần hóa DNNN là quá trình chuyển từ sở hữu đơn nhất là công hữu sang đa dạng hóa sở hữu $\mathrm{DNNN}$. Quá trình đó làm phong phú và sinh động hơn sự tồn tại lâu dài của các thành phần kinh tế... Đây là một thực tế đang vận động trong cuộc đấu tranh tư tưởng giữa giáo điều với sáng tạo lý luận trên phương diện kinh tế, nhất là với sự lo sợ về tư nhân hóa tư liệu sản xuất công. Chính vì vậy quá trình cổ phần hóa DNNN cũng có không ít những thăng trầm, nhưng lại đầy tính đột phá.

\section{Thăng trầm}

Những bước thăng trầm, cam go của quá trình tiến hành cổ phần hóa $\mathrm{DNNN}$ có thể hình dung qua các thời kỳ như sau:

\section{Thời kỳ làm thử và thí điểm:}

Thời kỳ này được khởi động từ năm 1992 đến 1996, cổ phần hóa DNNN đã được làm thử, thí điểm ở một số ít các doanh nghiệp. Diện được lựa chọn làm thử là các doanh nghiệp vừa và nhỏ, kinh doanh có hiệu quả và thuộc diện Nhà nước không cần nắm giữ $100 \%$ vốn, tập thể và công nhân viên chức tự nguyện tham gia thí điểm thì được chọn theo tinh thần của Quyết định số 202/CT, ngày 08-06-1992, và Chỉ thị số 84/TTg, ngày 04-08-1993, của Thủ tướng Chính phủ. Trong vòng 5 năm thí điểm, chỉ chuyển được $5 \mathrm{DNNN}$ thành công ty cổ phần. Điều đó càng cho thấy, sự khởi đầu quá trình cổ phần hóa DNNN đã diễn ra rất thận trọng và hoàn toàn không phải là một quá trình 
đơn giản.

Thời kỳ mở rộng thi điểm:

Thời kỳ này diễn ra từ năm 1996 - 1998. Trên cơ sở tổng kết thí điểm, đánh giá kết quả thí điểm, Chính phủ ban hành Nghị định số 28/CP, ngày 07-05-1996, về chuyển một số DNNN thành công ty cổ phần. Kết quả là đã chuyển được thêm 25 doanh nghiệp thành công ty cổ phần (CTCP). Mặc dù, về số lượng gấp 5 lần thời kỳ đầu, nhưng vẫn còn quá thấp so với yêu cầu đổi mới DNNN. Tốc độ cổ phần hóa đó được coi là quá chậm chạp.

Thời kỳ cổ phần hóa DNNN được đẩy mạnh và mở rộng:

Chuyển biến rõ rệt của quá trình cổ phần hóa DNNN được bắt đầu từ khi Chính phủ ban hành Nghị định số 44/1998/NĐ-CP. Chỉ trong hơn 1 năm, từ khi Chính phủ ban hành Nghị định số 44/1998 /NĐ-CP, ngày 2-6-1998, đến ngày 31-12-1999, có 340 doanh nghiệp và bộ phận doanh nghiệp chuyển thành CTCP. Chỉ tính riêng nửa cuối của năm 1998 đã tiến hành cổ phần hóa và đa dạng hóa sở hữu được 90 doanh nghiệp. Riêng năm 1999 đã có 250 doanh nghiệp, gấp 8 lần so với 7 năm trước cộng lại. Như vậy, sau khi có Nghị định số 44/1998/NĐ-CP, về mặt số lượng, tốc độ cổ phần hóa được đẩy mạnh. Nhiều bộ, ngành, địa phương, tổng công ty nhà nước đã tích cực thực hiện và có những kết quả rất đáng khích lệ.

Nhìn chung, sau khi có Nghị định số 44/1998/NĐ-CP của Chính phủ, cổ phần hóa DNNN đã đạt được những tiến bộ đáng kể. Nhận thức và hành động của các bộ, ngành, địa phương có chuyển biến hơn. Nghị định này đã quy định các chính sách khuyến khích đối với doanh nghiệp và người lao động trong doanh nghiệp cổ phần hóa một cách rõ ràng, cụ thể hơn, có sự quan tâm đặc biệt đến quyền lợi của người lao động.

Điều đó đã khiến chủ trương cổ phần hóa trở nên hấp dẫn hơn đối với doanh nghiệp cũng như đối với người lao động và các đối tượng khác trong xã hội.

Giai đoạn cổ phần hóa DNNN đi vào chiều sâu:

Chính phủ ban hành Nghị định số 64/2002/NĐ-CP, ngày 19-6-2002, với nhiều điểm mới và quy định mới nhằm đẩy nhanh tiến độ cổ phần hóa. Đến hết năm 2001, cả nước đã tiến hành đa dạng hóa sở hữu thành công ty cổ phần được 727 đơn vị. Riêng từ tháng 1-2000 đến cuối tháng 11-2002, cả nước đã cổ phần hóa được 523 doanh nghiệp.

Như vậy, có thể thấy tốc độ cổ phần hóa các DNNN càng được đẩy mạnh. Hơn nữa, càng về sau các doanh nghiệp có quy mô lớn đã thực thi. Điển hình là trước năm 2003, số doanh nghiệp cổ phần hóa có vốn trên 10 tỉ đồng chỉ chiếm 7,9\% thì năm 2003 là $15 \%$. Điều này cũng chứng tỏ sự kiên quyết cũng như tính nhất quán trong việc thực hiện chủ trương sắp xếp lại các $\mathrm{DNNN}$ của Đảng và Nhà nước ta. 
Từ năm 2003 - 2005, sau Nghị định số 64/2002/NĐ-CP, Nghị định số 184/ 2004/NĐ-CP, ngày 16-11-2004, được ban hành. Bước đổi mới cơ bản của Nghị định 184 là xóa bỏ tình trạng cổ phần hóa "khép kín", đẩy mạnh thị trường hóa cổ phần hóa, bán đấu giá công khai cổ phần, đã cơ bản khắc phục được tình trạng trên. Trong thời gian này quá trình cổ phần hóa đến hồi quyết liệt, đi vào chiều sâu và đạt những thành tựu rất khả quan. Trong giai đoạn này, số doanh nghiệp được cổ phần hóa là 2.039 đơn vị, gấp hơn 2 lần những năm trước. Điều này cho thấy, mỗi bước chuyển qua các nghị định là sự đúc kết, rút kinh nghiệm từ thực tiễn và liên tục hoàn thiện cho phù hợp hơn với mục tiêu chiến lược cổ phần hóa.

Theo báo cáo của Ban Chỉ đạo Đổi mới và Phát triển doanh nghiệp nhà nước, tính đến thời điểm 31-12-2005, cả nước đã thực hiện cổ phần hóa được 2.242 doanh nghiệp nhà nước, với tổng số vốn của các doanh nghiệp cổ phần hóa lên tới 17.700 tỉ đồng, bằng $8,2 \%$ toàn bộ vốn nhà nước tại doanh nghiệp. Tính bình quân trong các doanh nghiệp cổ phần, Nhà nước nắm giữ $46,5 \%$ vốn điều lệ; cán bộ, người lao động trong doanh nghiệp nắm $38,1 \%$, ngoài doanh nghiệp nắm $15,4 \%$. Qua cổ phần hóa, đã huy động được khoảng 12.411 tỉ đồng của các cá nhân, tổ chức ngoài xã hội đầu tư vào doanh nghiệp, Nhà nước thu lại được khoảng 10.169 tỉ đồng. Vốn của Nhà nước tại các doanh nghiệp nhà nước chưa cổ phần (tính đến ngày 31-12-2004) còn khoảng 200.000 tỉ đồng. Khai thác, thu hút và sử dụng có hiệu quả các nguồn vốn này sẽ tạo điều kiện thuận lợi để đẩy nhanh tiến trình công nghiệp hóa, hiện đại hóa đất nước.

Sau khi Nghị định 184 ra đời, hiện tượng cổ phần hóa "khép kín" trước đây đã được giải quyết bằng cách bán đấu giá cổ phần; số cổ phần bán cho những người trong nội bộ công ty được quy định bằng một tỷ lệ giá nhất định so với giá bán ra bên ngoài.

Theo phương án sắp xếp doanh nghiệp nhà nước đã được Chính phủ phê duyệt, giai đoạn 2007 2010 cần sắp xếp hơn 1.500 doanh nghiệp, trong đó cổ phần hóa hơn 900 doanh nghiệp.

Thế nhưng, trong hai năm 2007 - 2008, chỉ sắp xếp được 266 doanh nghiệp trong đó cổ phần hóa 155 doanh nghiệp. Hết quý I-2009, cả nước cũng chỉ sắp xếp được 24 doanh nghiệp, trong đó cổ phần hóa 13 doanh nghiệp.

Phó Trưởng Ban thường trực Ban Chỉ đạo Đổi mới và Phát triển doanh nghiệp Phạm Viết Muôn cho biết, tính đến tháng 10-2010, cả nước đã cổ phần hóa được 3.960 doanh nghiệp và bộ phận doanh nghiệp. Nếu so với số liệu cuối năm 2008 là 3.836 doanh nghiệp, trong gần 2 năm qua con số doanh nghiệp được cổ phần hóa mới đạt 124 đơn vị. Tiến trình cải cách doanh nghiệp gần đây đã bị chậm lại.

Tính đến tháng 10 -2010, có 6.140 doanh nghiệp nhà nước được chuyển đổi sang mô hình cổ phần hóa, giao, bán, khoán, giải thể, hay phá sản...

Đến nay, cả nước hiện còn 1.200 doanh nghiệp 100\% vốn nhà nước, tập trung ở những lĩnh vực độc quyền nhà nước, công ích, an ninh quốc phòng; những ngành, lĩnh vực bảo đảm cân đối vĩ mô hoặc 
cung cấp dịch vụ thiết yếu cho xã hội...

Qua sắp xếp, đến nay doanh nghiệp nhà nước tập trung ở những doanh nghiệp quy mô lớn với 11 tập đoàn và 87 tổng công ty nhà nước hoạt động trong các ngành quan trọng của nền kinh tế.

\section{Đột phá}

Nhìn qua các thời kỳ của quá trình cổ phần hóa DNNN, có thể thấy, càng về sau, tiến độ thực hiện cổ phần hóa thường có những bước tiến mạnh mẽ hơn gắn với thời điểm có những quyết định pháp lý quan trọng về cổ phần hóa ra đời. Vai trò động lực thúc đẩy thực tiễn của chủ trương, chính sách thể hiện khá rõ nét. Đây chính là tính đột phá của cơ chế, chính sách làm cho những sự chần chừ, do dự về tư tưởng, cũng như băn khoăn về lợi ích thiển cận đều được vượt qua.

Các DN cổ phần hóa thời gian qua đã chứng minh được hiệu quả hoạt động. Việc đa dạng hóa sở hữu sẽ giúp chúng ta có thêm nguồn vốn, kênh đầu tư và quản trị DN tốt hơn. Nhà nước không cần thiết phải nắm một số lượng lớn doanh nghiệp và trong tất cả các lĩnh vực của nền kinh tế cũng chính là một khâu đột phá về tư duy kinh tế. Cổ phần hóa DN nhà nước - với một cơ chế quản lý phù hợp hơn - sẽ là giải pháp hữu hiệu giúp các doanh nghiệp vận hành tốt trong cơ chế thị trường. Đó chính là bước thay đổi về chất đối với quản lý, điều hành các doanh nghiệp.

Có thể khái quát một số nét cơ bản về hoạt động của các doanh nghiệp sau cổ phần hóa:

- Ngay trong năm đầu tiên sau cổ phần hóa, doanh thu bình quân, lợi nhuận sau thuế của phần lớn các doanh nghiệp đều tăng.

- Nhiều năm hoạt động sau cổ phần hóa cho thấy, các công ty cổ phần đều ổn định, tốc độ tăng trưởng của doanh nghiệp được duy trì.

- Sau cổ phần hóa, các doanh nghiệp phát triển sản xuất kinh doanh, tạo thêm công ăn việc làm, thu hút thêm lao động. Hầu hết các doanh nghiệp đều có mức cổ tức cao hơn mức tiền gửi ngân hàng.

- Dư luận xã hội đều cho thấy cái được lớn nhất của cổ phần hóa là đặt doanh nghiệp vào môi trường công khai, minh bạch. Mọi động thái của doanh nghiệp đều phải báo cáo công khai trước cổ đông. Hằng quý, nửa năm và mỗi năm đều phải công khai báo cáo tài chính có xác nhận của kiểm toán độc lập. Chính môi trường tích cực này đã làm nảy sinh ý tưởng cho rằng, đối với các công ty trách nhiệm hữu hạn một thành viên, tổng công ty nhà nước và tập đoàn kinh tế nhà nước, có lẽ cũng cần phải được báo cáo công khai, minh bạch để toàn dân được biết như các công ty cổ phần.

Vài năm gần đây, do các doanh nghiệp phải đối phó với khủng hoảng tài chính kinh tế thế giới (2008 - 2009), nên chưa thể tập trung cho việc chuyển đổi sở hữu mạnh mẽ hơn nữa. Suy giảm kinh tế, thị trường chứng khoán đi xuống... đã khiến việc đấu giá cổ phần lần đầu (IPO) khó mang lại giá tốt. Nhưng theo Hiệp hội Các nhà đầu tư tài chính Việt Nam, càng chậm trễ cổ phần hóa, thì doanh nghiệp nhà nước càng chậm tiếp cận với môi trường sản xuất, kinh doanh mới, vì thế càng mất cơ 
hội để tạo đột phá về sức cạnh tranh. Điều này đồng nghĩa với việc Nhà nước bị thua thiệt trong dài hạn.

Tuy nhiên, cũng có ý kiến lại cho rằng, không nên vì sức ép về kế hoạch số lượng mà "bán rẻ" doanh nghiệp. Bởi vậy, nên chọn tiến độ cổ phần hóa phù hợp, nhằm vừa không làm ảnh hưởng đến sự hồi phục của thị trường chứng khoán, vừa không làm giảm nguồn thu từ việc bán phần vốn nhà nước.

Thế nhưng, điều quan trọng hơn cả có lẽ không phải là bán giá nào, mua giá nào tài sản của Nhà nước trong các DNNN khi thực hiện cổ phần hóa hay IPO, bởi vì khi đã là công ty đại chúng, thì việc lên, xuống của giá cổ phiếu là chuyện bình thường trong cơ chế thị trường nói chung, thị trường chứng khoán nói riêng. Cái được quan trọng nhất của cổ phần hóa là cải thiện môi trường hoạt động, nhất là công khai, minh bạch, hiệu quả. Cổ phần hóa chính là phương tiện, chứ không phải mục tiêu. Mà mục tiêu cuối cùng là đạt được hiệu quả. Khi hiệu quả cao đối với doanh nghiệp thì giá cổ phiếu ắt sẽ tăng lên cùng với môi trường kinh tế vĩ mô ổn định và thông thoáng./.

Đoàn Hiền 


\section{Tài liệu tham khảo:}

[1] Phạm Minh Chính, Vương Quân Hoàng. (2008). Bối cảnh tài chính Việt Nam 1997-1998 và 2007-2008: khoảng cách và biến đổi. Nghiên cưu Kinh tế, 48(7), 3-24.

[2] Phạm Minh Chính, Vương Quân Hoàng. (2009). Kinh tế Việt Nam: Thăng trầm và đột phá. Nxb Chính trị Quốc gia, Hà Nội. 